\title{
Trust Perception and Payment Method on Marketplace in Indonesia (Study on Shopee)
}

\author{
AIDA SARI ${ }^{1}$, MUDJI RACHMAT RAMELAN ${ }^{2}$, DINA SAFITRI $^{3}$, NUZUL INAS $^{4}$ \\ 1,2,3,4 Department of Management, Faculty of Economics and Business, Universitas Lampung, \\ INDONESIA
}

\begin{abstract}
The rapid development of e-commerce in Indonesia has led to the emergence of competition. One of the e-commerce platforms that is aggressive in promoting and widely used by Indonesian consumers is Shopee. Shopee conducts promotions in Indonesia to bring new shopping experiences to facilitate easy sales and provide shoppers with secure payment processes and integrated logistics arrangements. The research purpose is to determine reputation's effect, privacy, size, safeguard, web familiarity, and ease in creating a positive effect on confidence; and trust variable will have a positive effect on payment methods using the electronic payment system (EPS), credit cards and cash on delivery on product purchases at online shops in Indonesia. The research methodology uses quantitative methods with a cross-sectional research design by distributing questionnaires online with a Google Form, with 248 respondents. The study led to the findings of the perceptions of trust significantly influenced by security, benefits, and convenience, while reputation, privacy, size, and web familiarization do not affect trust. Furthermore, trust affects the electronic payment method (EPS), credit card, and cash on delivery. The limitation of the study is in the sampling method which covers not all regions in Indonesia. Contribution: as a company, Shopee should maintain security, the benefits, and convenience to develop strategies using electronic payment methods.
\end{abstract}

Keywords: Online Shop, E-commerce, trust and method of payment.

Received: May 9, 2021. Revised: December 4, 2021. Accepted: January 3, 2022. Published: January 4, 2022.

\section{Introduction}

E-commerce has defined as buying process, retailing, and commercialized the goods and services electronically as business transaction, both $\mathrm{B} 2 \mathrm{C}$ and or B2B by using the internet. Ecommerce has become a business alternative in the modern era which is in line with increasingly dynamic market conditions and competitive competition, resulting in changes in consumer behavior.

According to Tech in Asia, there are fivebusiness models of E-commerce in Indonesia, including classified ads, marketplaces C2C, shopping malls, B2C stores, and online stores on social media. One of the marketplace applications currently being used in Indonesia is Shopee, that benefits the E-commerce business by using mobile devices. Shopee positions itself as a marketplace application. Shopee exists in Indonesia to bring a new shopping experience, facilitate easy sales, and equip buyers with secure payment processes and integrated logistics arrangements.

Maqableh et al. (2015) stated that the payment system that will be resolved through the application system faces many threats; therefore, the system of remittance is deliberated to keeping the safeguard and data protection, and has the technique to produce reliable transaction records. The problem of consumer confidence in safety of personal data protection of online remittance is necessary because electronic payment systems have been habituated as a common media for banking transactions. Some of banking activities such as payments and transfers now shift to mobile devices that offers more flexibility in time and place. Mobile transaction is considered as an effective and efficient way than the traditional financial transactions. 
Sumanjeet (2009) stated that the electronic payment system method is a challenge because it includes elements of trust measurement as part of customer payment services using payment methods, and requires efforts to convince people who have an experience of being dissatisfied with online payment systems, and prefer to make payments in cash due to the consideration of the trust factor. The most considerably reason is trust insufficiency from the customers that experience frequent failures, online fraudulence, the limited number of electronic payments options, that breeds the uncertainty of the users for using such of technology. The product itself usually does not exist during transactions through E-commerce platforms, so the lack of trust and acceptance becomes important for customers. This research is expected to yield valuable insights into how customers behave when using Shopee's payment methods.

\section{Problem Formulation}

\subsection{Problem formulation and Hypothesis}

Some studies only link between the factors that influence trust in the marketplace, and very rarely in developing countries that focus on trust factors that affect the payment system to be made. Therefore, the formulation of the problem in this study is whether perceptions of reputation, privacy, size, security, benefits, and convenience form a positive influence on perceptions of trust and whether trust has a positive effect on purchases using EPS (Electronic Payment System), credit cards and cash on delivery (COD).

Based on the description of the former research, we construct the first hypothesis,:

- H1: Perceptions of reputation, privacy, size, security, benefits, website user friendly, and convenience have a significant impact to trust.

Kim et al. (2010) indicated that the payment system is a perception of user friendly and usefulness. There are six elements that affect electronic payment systems, consisting of safeguard, user friendly, trustworthiness, interoperability, common problems, and additional services. Based on the six factors above, a lot of effort is needed to generate mutual trust between traders and customers in online shopping. Nuri (2014) stated that security and trust contribute pivotal role to

\section{Privacy standpoint}

Claire (2004) explains that privacy is a form of personality protection. This explanation explains that privacy is a situation where someone is allowed to keep individual information. In addition, privacy is defined as the ability of individuals to manage the completeness of personal information, where the information will be needed and used by other parties (Ackerman and Culnan, 2002). In e-commerce, privacy itself is defined as the willingness of consumers to provide information via the internet before deciding to buy an item (Ackerman and Culnan, 2002). Concerning other people, humans have a reference to the level of privacy they want.

The relationship between privacy space in e-commerce is that privacy is the willingness of consumers to provide information via the internet before someone decides to buy an item (Ackerman, 2002); and Culnan (2000). Privacy on the internet includes 'spam,' data, choices, and information sharing with e-commerce service providers. Consumers also ask for assurances that the information they provide is limited and regulated by the person concerned (Belanger, 2002) and (Hoffman, 1999).

Everyone has severe protection of the privacy of each individual. The information they provide to sellers in e-commerce is given by customers very carefully (Hoffman, 1997). When a consumer maintains their privacy, they usually prefer to provide incomplete information to internet providers. The privacy provided to a website carries a risk of misuse of that information. In other words, the more a person feels that a web address well guards the information provided, the higher the level of one's trust in a web address will be. (Franzak, 2001).

The privacy standpoint above raises one hypothesis below, namely:

- H2: Perceived privacy forms a positive impact on trust

\section{Measurement standpoint}


Perception of size refers to a buyer's perception of the company's size as being more significant than the size of the existing store/office (Jarvenpaa, 2000). According to Doney (1997) in Jarvenpaa (2000), perception is one metric by which a large company's size can persuade other consumers to trust it, and many companies are successful at it.

A large size indicates that the business can handle product or service failures and compensate its customers (Jarvenpaa, 2000). A large company's characteristics must also include controlling its suppliers and services, as the more significant the company, the more other parties invest in it.

Hypotheses that can be built from the explanation above are:

- H3: Perception of firm size forms a positive impact on Trust.

\section{Security standpoint}

E-commerce security is a significant control issue for companies that run e-commerce (Laudon and Laudon, 2005). Data related to ecommerce, such as buyer and seller data, must be kept confidential when consumers are in electronic transmission. Additionally, the transmitted data must be protected from being altered or modified by anyone other than the sender (Belanger, 2002).

According to Audun (2007), security, in general, can be interpreted as a state of being free from danger. This understanding is comprehensive and includes a person's sense of protection from intentional and unintentional crimes, such as natural disasters. A security threat is defined as a situation, condition, or event that has the potential to damage data or networks, which can be in the form of destruction, leakage, alteration, and misuse of data (Kalakota and Whinston, 1996) in (Belanger, 2002).

Consumer security concerns in e-commerce can be addressed through the use of protection technology. These technologies are categorized as security features when they are used (Belanger, 2002).

According to Icove (2000), based on security holes, security can be classified into four, namely: physical security (physical security), security related to people (personnel), data security (data security), and media and communication techniques (communications). ).

Security in operations includes policies and procedures used to set up and manage security systems and post-attack recovery procedures. The management of the security of the online payment system can be seen from the side of risk management. Rahardjo (2005) suggests using the "Risk Management Model" to deal with threats (managing threats).

Three components contribute to risk, namely assets, vulnerabilities, and threats. Ecommerce network security that provides features such as guarantees, contracts, or other procedures ensures that payment security exists and runs well (McKnight, 2002 and Shapiro, 1987).

Someone who has a high perception of structural assurance will firmly believe that internet technology (e.g., data encryption) protects so that someone believes that transactions via the internet can run safely (McKnight, 2002).

Encryption, legal protection, and technology safeguards keep consumers from losing money and privacy. According to Gefen (2003), security guarantees can be built into ecommerce sites through collaboration with third parties who have a good reputation in network security issues and provide internet security assurance standards with web assurance seals such as Verisign E-TRUST, Good House Keeping, and CPA Web Trusts.

Consumers who feel safe with the internet environment will tend to trust websites that provide electronic commerce services compared to people who feel that the internet is not safe because they do not believe that there is adequate protection on e-commerce sites.

From this theory, the fourth hypothesis is generated, namely:

- H4: Perceived security has a positive impact on trust

\section{Benefit standpoint}

Rahmatsyah (2011) defines perceived usefulness as the subjective probability of potential users using a particular application to facilitate the performance of their work. This 
simplified performance can produce better physical and non-physical, such as the results obtained will be faster and with more satisfying results compared to not using the product with the new technology. According to Mangin et al., (2008:14).

Perception of benefits is defined as the degree to which a person believes that using technology will increase his/her performance at work, meaning that the benefits of internet banking facilities will be able to increase performance productivity for people who use the facility.

According to Almuntaha (2008:14), user perceptions of the benefits of technology can be measured from several factors:

- The use of technology can increase user productivity.

- The use of technology can improve user performance.

- The use of technology can increase the efficiency of user processes.

The hypotheses that can be built from the literature review above are:

- H5: Perceived benefits form a positive impact on trust

\section{Engagement standpoint}

Marofi et al. (2012), examines and observes consumer behavior and impressions of security and trust in e-payment systems based on proximity to the website. Rouibah (2012) found several influencing variables, including internet experience, personal innovativeness, habit, tendency to trust. The presence of a third party, the intention when using the e-payment system through the connecting variables, the perception of pleasure, the perception of risk, and trust.

Koufaris and Hampton-Sosa investigated the level of consumer confidence in the company's business website after the customer's first visit to the company's website. The investigation results found that consumer perceptions of the company's reputation and willingness to improve goods and services have a tangible impact on consumer confidence.

In addition, usability, ease of use, and security controls are also suspected of having a significant impact on trust.
The hypotheses raised from the above theory are:

- H6: Familiarity with the website builds consumer trust

\section{Convenience standpoint}

Jogiyanto (2009) states that perceived ease of use is defined as the extent to which a person believes that using technology will be free from effort. As implied by definition, ease perception is a belief about the decision-making process. If a consumer believes an information system is straightforward to use, he or she will use it.

Sun and Zhang (2011) identified the dimensions of perceived ease, namely, ease to learn (easy to learn), ease to use (easy to use), clear and understandable (straightforward and easy to understand), and become skillful (becoming skilled).

The hypothesis that emerged from the theory above is:

- H7: Perceived convenience forms a positive impact on trust

\section{Trust standpoint}

The primary determinant that affects ecommerce is trust that the trust strongly influences consumer behavior on the internet. Besides that, it can increase social status and make purchases in the marketplace (Gefen, 2000).

The study conducted by Tan and Thoen (2001) focused on two main activities, namely electronic payments, and cross-border trade, introducing a model of the level of trust depending on the individuals involved in the transaction, that the two main factors of the level of trust in transactions are the trust of other parties and control mechanisms. Both of these factors have objective and subjective aspects.

With the high level of uncertainty and dynamics in cyberspace, trust appears and is determined as a direct determinant of attitude (Gefen and Straub, 2003; Hassanein and Head, 2007; Lin, 2011).

Trust can also be referred to as one's belief in trusting others which can be determined by perceived integrity, benevolence, and competence (McKnight et al., 2002; Lin, 2011). 
Simply put, trust can be described as the expectation that others will not behave opportunistically and that the vendor will deliver what has been promised (Gefen et al., 2003).

Trust is emphasized as one factor that significantly influences e-commerce (Abbad et al., 2011), especially online shopping (Faqih, 2011). According to Abbad et al. (2011), trust and security are among the primary constructs for e-commerce.Higher quality e-commerce sites usually result in higher perceptions of trust (Hsiao et al., 2010). The context of building trust is a very challenging process and critical in shaping consumer attitudes in a developing country (Lee et al., 2010; Al-Debei and A1Lozi, 2014).

\section{Payment methods standpoint}

Tsiakis and Sthephanides (2005) imply that trust and security are two crucial and essential determinants for any electronic payment system used as a medium for financial transactions. Kim et al. (2010) stated that the payment system perceives ease of use and usefulness. Nuri (2014) stated that security and trust were found to play an essential role in attracting and gaining customer loyalty.

The description of previous studies as described above builds several hypotheses, namely:

H8: Perceived trust has a positive impact on purchase intention using EPS

H9: Perceived trust has a positive effect on actual purchases using credit cards

H10: Perceived trust has a positive effect on actual purchases using cash on delivery.

\subsection{Research Method}

The methodology that is applied for this study is a quantitative method, that use a cross- sectional research design where data collection activities are carried out from one respondent at a time. The population and sample of this research are buyers at online Shopee in Indonesia by applying non-probability sampling or with a sampling method, which is convenience sampling, namely members of the population who are selected based on the judgment from the researchers.

The number of samples in research using PLS (partial least square) SEM must have a minimum of five times the number of questions in the questionnaire (Hair et al., 2014), so the total number of questionnaires in this study is 5 $\mathrm{x} 44$ questions so that the respondents in this study are 220 respondents.

The research questionnaire was designed by using closed questions in which each variable to be examined using five measurement scales (Likert). In distributing research questionnaires, we use Google-Form by sending questionnaire links online and explain what will be done to respondents via social media such as WhatsApp, Line, direct massage on Instagram and other social media so that it can speed up and also make it easier for respondents to fill out them and the results will be stored digitally.

The components in this research were adopted from the research of Maqableh et al. (2015) which is closely related to trust behaviour and online shopping payment methods for Shopee in Indonesia (Appendix 1). All constructs in this study were measured by a Likert scale, and used a 5-point scale from 1 with information "strongly disagree" to 5 "strongly agree".

The fit test of the overall PLS SEM model can be seen in TABLE 1, which shows the fit results. It can be seen that the structural model testing phase (inner model) can be done using the following Good of Model Fit.

Table 1. Goodness of Model Fit

\begin{tabular}{|c|c|c|c|}
\hline Goodness Model of Fit & $\begin{array}{c}\text { Original Value (Saturated } \\
\text { Model) }\end{array}$ & Estimated Model & Note \\
\hline SRMR & 0.067 & 0.099 & Model Fit \\
\hline d_ULS & 4.430 & 9.688 & Model Fit \\
\hline d_G & 1.537 & 1.703 & Model Fit \\
\hline
\end{tabular}

Source: Data Analysed with Smart PLS Version 3 
The result of the SRMR (referred to the Standardized Root Mean Square Residual) figure is the level of prediction error for the independent variable on the dependant variable. The residual estimate in this research is the smaller original value of 0.1 . d_ULS (The Squared Euclidean Distance) and d_G (The Geodesic Distance) define that a representative research model must indicate the figure that is bigger than 0.05 (if using a $95 \%$ confidence interval) or $>0.01$ (if using a $99 \%$ confidence interval). This means that the research model has a low residual distribution. Then the validity test is valid by looking at the square root of average variance (AVE) value which has a loading factor above 0.5 and the reliability test results can be seen from the results of composite reliability having a value above 0.7 or can also be strengthened by Conbach's Alpha. (Appendix 2).

\section{Problem Solution}

The results of distributing questionnaires were conducted on a non-probability basis through Google-Form collected 248 which can be processed into research data. The profiles of respondents who filled out the questionnaire are as follows:

Table 2. Respondent Characteristic

\begin{tabular}{|c|c|c|c|}
\hline Type of Characteristic & Characteristic & Total & Percentage \\
\hline \multirow[t]{2}{*}{ Sex } & Male & 78 & $31,45 \%$ \\
\hline & Female & 170 & $68,55 \%$ \\
\hline \multirow[t]{4}{*}{ Age } & $18-30$ years old & 194 & $78,23 \%$ \\
\hline & $30-40$ years old & 15 & $6,05 \%$ \\
\hline & $40-50$ years old & 21 & $8,47 \%$ \\
\hline & $>50$ years old & 18 & $7,25 \%$ \\
\hline \multirow[t]{4}{*}{ Occupation } & Students & 147 & $59,27 \%$ \\
\hline & Private-Company Employees & 43 & $17,34 \%$ \\
\hline & Civil Servants & 47 & $18,95 \%$ \\
\hline & State-owned Enterprise Employees & 11 & $4,44 \%$ \\
\hline \multirow[t]{4}{*}{ Income } & $<$ IDR 3 millions & 173 & $69,35 \%$ \\
\hline & IDR 3 millions up to IDR 6 millions & 50 & $20,16 \%$ \\
\hline & IDR 6 millions up to IDR 9 millions & 15 & $6,05 \%$ \\
\hline & $>$ IDR 9 millions & 11 & $4,44 \%$ \\
\hline \multirow[t]{4}{*}{ Shopping Frequency } & $<3$ times & 87 & $34,68 \%$ \\
\hline & 6 times & 65 & $26,21 \%$ \\
\hline & 9 times & 20 & $8,06 \%$ \\
\hline & $>12$ times & 77 & $31,05 \%$ \\
\hline \multirow[t]{4}{*}{ Shopping Cost } & $<$ IDR 1.5 millions & 188 & $75,40 \%$ \\
\hline & IDR 1.5 millions up to IDR 3 millions & 49 & $19,76 \%$ \\
\hline & IDR 3 millions up to IDR 4.5 millions & 4 & $1,61 \%$ \\
\hline & $>$ IDR 4.5 millions & 8 & $3,23 \%$ \\
\hline
\end{tabular}

The results of the distribution of the questionnaires of this study indicate that most of the respondents who shop online at Shopee are women with the respondents of the millennial-age group, which is 78,23 percent and the shopping frequency more than 12 times of 31,05 percent. This group is the most active in shopping online at Shopee. This happens because consumer confidence in the security of the online payment system is needed (Maqableh et al., 2015).

Table 3. Determinant coefficients

\begin{tabular}{|l|r|}
\hline \multicolumn{1}{|c|}{ Model } & R Square \\
\hline Perceived trust & $\mathbf{0 . 6 4 4}$ \\
\hline Purchase intention to use EPS & $\mathbf{0 . 4 3 8}$ \\
\hline Actual purchase using credit & $\mathbf{0 . 0 1 6}$ \\
\hline $\begin{array}{l}\text { Actual purchase using on } \\
\text { delivery }\end{array}$ & $\mathbf{0 . 0 2 3}$ \\
\hline
\end{tabular}


The findings of the coefficient of determination show that the effect of total reputation perception, privacy perception, scale perception, safeguard perception, perceived usefulness, user friendly perception, and trust perception by $64,4 \%$ percent. The trust perception variable intention to buy by EPS contributed $43,8 \%$. Trust perception towards factual buying using credit card contributed
$1,60 \%$ and the variable trust perception towards factual buying using on cash-ondelivery contributed $2,30 \%$.

After going through the coefficient of determination, the next stage is testing the hypothesis, which is the last stage after all the parameters have been known.

Table 4. Hypothesis Test

\begin{tabular}{|l|c|c|c|c|c|l|}
\hline \multicolumn{1}{|c|}{ Model } & $\begin{array}{c}\text { Original } \\
\text { Sample }\end{array}$ & $\begin{array}{c}\text { Mean of } \\
\text { the ample }\end{array}$ & $\begin{array}{c}\text { Standard } \\
\text { Deviation }\end{array}$ & T-Value & P-Value & Note \\
\hline $\begin{array}{l}\text { Reputation perception - } \\
\text { > perceived trust }\end{array}$ & 0.043 & 0.054 & 0.070 & 0.613 & 0.540 & Not significant \\
\hline $\begin{array}{l}\text { Privacy perception } \\
->\text { Trust perception }\end{array}$ & 0.119 & 0.117 & 0.064 & 1.841 & 0.066 & Not significant \\
\hline $\begin{array}{l}\text { Scale perception -- } \\
\text { > Trust perception }\end{array}$ & 0.003 & 0.002 & 0.059 & 0.047 & 0.963 & Not significant \\
\hline $\begin{array}{l}\text { Privacy perception -> } \\
\text { Trust perception frust }\end{array}$ & 0.456 & 0.452 & 0.059 & 7.749 & 0.000 & significant \\
\hline $\begin{array}{l}\text { Perceived usefulness } \\
\text { (PU)-> } \\
\text { perception -> }\end{array}$ & 0.150 & 0.155 & 0.059 & 2.560 & 0.011 & significant \\
\hline $\begin{array}{l}\text { User } \\
\text { perception (PE) - } \\
\text { Trust perception }\end{array}$ & 0.030 & 0.020 & 0.082 & 0.363 & 0.716 & Not significant \\
\hline $\begin{array}{l}\text { Perceived ease of use - } \\
>\text { Trust perception }\end{array}$ & 0.156 & 0.162 & 0.070 & 2.227 & 0.026 & significant \\
\hline $\begin{array}{l}\text { Perceived trust -> } \\
\text { Intention of buying by } \\
\text { employing EPS }\end{array}$ & 0.662 & 0.665 & 0.032 & 20.645 & 0.000 & significant \\
\hline $\begin{array}{l}\text { Perceived trust -> } \\
\text { Factual buying by } \\
\text { credit cards }\end{array}$ & 0.127 & 0.134 & 0.064 & 1.986 & 0.048 & significant \\
\hline $\begin{array}{l}\text { Perceived trust -> } \\
\text { Factual buying with } \\
\text { cash-on-delivery } \\
\text { system }\end{array}$ & 0.152 & 0.157 & 0.061 & 2.484 & 0.013 & significant \\
\hline
\end{tabular}

\section{Hypothesis results}

- H1 Reputation Perception is not significant to perceived trust seen from the P-value 0.540 . The first hypothesis is not supported. Unlike previous research conducted by (Gul, Roshana 2014) proved that reputation is positive and significant to trust.

- H2 Privacy perception is not significant to Trust perception seen from P-value 0.066. Hypothesis 2 does not support
- H3 Scale perception is not significant to trust perception seen from the P-value 0.963 . The third hypothesis does not support

- H4 Privacy perception is significant to Trust perception as seen from the P-value 0.000 . The 4th hypothesis supports

- H5 Perceived usefulness is significant to trust perception seen from the P-value of 0.011 . The 5 th hypothesis supports

- H6 User-friendly perception is not significant to Trust perception seen from P- 
value 0.716 . The 6th hypothesis does not support

- H7 Perceived ease of use is significant to Trust perception as seen from the P-value 0.026 . The 7 th hypothesis supports

- H8 Perceived trust is significant on Intention of buying by employing EPS as seen from the P-value 0.000 . The 8th hypothesis supports

- H9 Perceived trust is significant to the factual buying by credit cards seen from the P-value 0.048. The 9th hypothesis supports

- H10 Perceived trust is significant on factual buying with cash-on-delivery system seen from P-value 0.013

These results show that there is an implication of belief-formers on online shopping on Shopee application in Indonesia, which is determined by safety, benefits, and convenience factors that have a very significant effect. This supports the research of Abbad et al (2011) where trust and safeguard are two main constructs for E-commerce. High calibre Ecommerce sites gain bigger perception of trust from its customers (Hsiao et.al, 2010) and the remarkable actions to gain customer's trust will form the consumer attitudes in a developing country (Lee et al., 2010; Al-Debei and AlLozi, 2014).

These results indicate that there are findings related to the willingness of customers who shop online through the Shopee application, is that they will buy products from Shopee by making payments via EPS. This finding supports the research of Tsiakis and Sthephanides (2005), the credence and safeguard are most pivotal and indispensable factors for electronic payment system that is applied as the tool to financial activities. In addition, Nuri (2014) stated that security and trust are important roles in attracting and earn customer loyalty.

The findings also prove the trust perception is influenced by the safety, benefits, and convenience of shopping online at Shopee in Indonesia, and the perception of the payment method for purchasing the most influential factor is by using EPS. Therefore, marketplace service providers such as Shopee might build trust by focusing on the safety, benefits, and convenience of doing online shopping. Further for the long term, service providers may develop payment methods through EPS. Consumers will be most likely to make purchases online at Shopee with a high level of trust and payment methods via EPS. If trust, security, ease of payment have been satisfied by consumers, consumers will be directly recommended about the online services offered by shopee in Indonesia.

\section{Conclusion}

Based on the results of the research conducted by using of PLS SEM, the trust variable is a multidimensional construct consisting of reputation, privacy, size, benefits, security, benefits, web familiarity, and convenience. This result shows that the p-value is not all indicators that have loading to the latent variable which is less than 0.05 .

This research proves that the factors that have a significant effect are the safety, benefits, and convenience of using Shopee as an ecommerce platform in Indonesia. In addition, this research also shows an eloquent impact of trust on payment methods using EPS, credit cards, and cash on delivery.

The implication for Shopee is to provide online shopping services such as how to build a security strategy, benefits, and convenience for consumers to access Shopee online and another strategic implication is to develop an electronic payment method (EPS). The use of EPS can be relied on in the payment system for online shopping and by providing a high-security risk and convenience, consumers will certainly be loyal to Shopee.

\section{References:}

[1] Abbad, M., Abbad, R., and Saleh, M. (2011), "Limitations of e-commerce in developing countries: Jordan case", Education, Business and Society: Contemporary Middle Eastern Issues, Vol. 4 No. 4, pp. 280-291.

[2] Al-Debei, M.M. and Al-Lozi, E. (2014), "Explaining and predicting the adoption intention of mobile data services: a 
value-based approach Computers in Human Behavior, Vol. 35, pp. 326-338

[3] Audun. Josang, 2007. Trust and Reputation System. The International Journal of Management Science, pp. 725 737

[4] Belanger, France et al. 2002. Trustworthiness in Electronic Commerce: The Role of Privacy, Security, and Site Attributes. Journal of Strategic Information Systems, 11. (Online), USA.

[5] D., Karahanna, E. and Straub, D.W. (2003), "Trust and TAM in online shopping: an integrated model", MIS Quarterly, Vol. 27 No. 1, pp. 51-90.

[6] Doney, P.M, \& Cannon, J.P. (1997). An Examination of the nature of trust in buyer- seller relationships. Journal of Marketing, Vol.30, Issue.2, MCB UP Ltd.

[7] Slater (1997), "Developing a customer value-based theory of the firm", Journal of the Academy of Marketing Science, Vol. 25 pp. $162-167$.

[8] Gefen, D. (2000) E-commerce: The Role of Familiarity and Trust. The International Journal of Management Science, 28, 725-737.

[9] Gefen, D. and Straub, D.W. (2003), "Managing user trust in $\mathrm{B} 2 \mathrm{C}$ eservices", E- service journal, Vol. 2 No. 2, pp.7-24.

[10] Gotsi, M. and Wilson, A. (2001), "Corporate reputation: seeking a definition", Corporate Communications: An International Journal, Vol. 6 No. 1, pp. 24-30.

[11] Hsiao, K., Lin, J., Wang, X., Lu, H. and $\mathrm{Yu}, \quad$ H. (2010), "Antecedents and consequences of trust in online product recommendations: an empirical study in social shopping", Online Information Review, Vol. 34 No. 6, pp. 935-953.

[12] Jarvenpaa, S. L., 2000. Consumer trust in an internet store. Information Technology and Management, Volume 1, pp. 45-71.

[13] Kim, C., Tao, W., Shin, N. and Kim, K.S. (2010) An Empirical Study of Customers' Perceptions of Security and Trust in E-Payment Systems. Electronic Commerce Research and Applications, 9, 84-95. use mobile payment. Computers in Human Behavior, 26, pp.310-32.

[14] Lee, I., Kim, J., Choi, B. and Hong, S.J. (2010), "Measurement development for cultural characteristics of mobile internet users at the individual level", Computers in Human Behavior, Vol. 26 No. 6, pp.1355-1368

[15] Lin, H.F. (2011), “An empirical investigation of mobile banking adoption: the effect of innovation attributes and knowledge-based trust", International Journal of Information Management, Vol. 31 No. 3, pp.252-260

[16] Mangin, Jean. P. L., Bourgault N., dan Guerrero M. M. 2008. Modelling Perceived Usefulness on Adopting Online Banking Through the TAM Model in A Canadian Banking Environment. Journal of Internet Banking and Commerce. (online), Vol. 16, No.1

[17] McKnight, D.H., Choudhury, V. and Kacmar, C. (2002), "Developing and validating trust measures for ecommerce: an integrative typology", Information Systems Research, Vol. 13 No. 3, pp.334-359

[18] Sarah Nyengerai, Divaries Jaravaza, Paul Mukucha, Ranganai Chirimubwe and Evans Manjoro. (2013). Determinants of Perception towards Private Label Brands in Zimbabwe: The Role of Familiarity, Store Image, Demographic Factors and Consumer Characteristics. Greener Journal of Business and Management Studies Vol. 3 (5), pp.224-230.

[19] Sumanjeet, S. (2009) Emergence of Payment Systems in the Age of Electronic Commerce: The State of Art. Global Journal of International Business Research,17-36.

[20] Tsiakis, T., \& Sthephanides, G. (2005). The concept of security and trust in electronic payments. Computers \& Security, 24(1), 10-1

[21] Faqih, K.M.S. (2011), "Integrating perceived risk and trust with technology acceptance model: an empirical assessment of customers' acceptance of online shopping in Jordan", 2011 International Conference on Research and Innovation in Information Systems (ICRIIS), I EEE, pp.1-5. 
[22] Nuri, H. (2014) A Study of Role of the Factors Influencing the Acceptance of EBanking. No. 3, 521-525.

[23] Hoffman, L.D. and Novak T.P. 1998. Building Consumer Trust in Online Environment: The Case for Information's Security. Project 2000 Working Paper. (Online), Vanderbilt University.

[24] Sun Zhang, 2011, Optimal VAr planning in area power system. International Conference on Power System Technology.

[25] Ackerman, Marks S., and Donald T. Davis, Jr. Privacy and Security Issues in E-Commerce. The New Economy Handbook. (Online), USA.

[26] Almuntaha, Eska. 2008. Faktor-Faktor yang Mempengaruhi Pengadopsian Teknologi Internet Banking oleh Nasabah di Indonesia. Skripsi. Yogyakarta: Fakultas Ekonomi Universitas Islam Indonesia

[27] C.Laudon, Kenneth \& P. Laudon, Jane. 2005. System Information Management

[28] Jogiyanto. (2008). Sistem Informasi Keperilakuan. Yogyakarta: Andi.

[29] Maqableh, M. (2012) Analysis and Design Security Primitives Based on Chaotic Systems for eCommerce. Durham University

\section{APENDIX 1. Variable Operational}

\section{Perceived Reputation (PR): (Adapted from}

\section{Maqableh et al., 2015)}

PR1 Shopee is most favorable website for shopping online

PR2 Shopee is a trusted website for shopping online

PR3 Shopee is the top-picked website for shopping online

PR4 Shopee cares about online customers

\section{Privacy perception (PP): (Adapted from}

\section{Maqableh et al., 2015)}

PP1 I believe that I recognize all the companies that benefited from data collection that I supply during my activities in Shopee

PP2 I understand the data that I have to supply to Shopee during a transaction
PP3 I am sure that the data I provide to Shopee is verifiable

PP4 I am convinced that my data will not be disclosed by Shopee without my permission

Scale perception (PS): (Adapted from

Maqableh et al., 2015)

PS1 Shopee is a giant firm

PS2 Shopee is one of biggest supplier's in industry for online shopping

PS3 Shopee is a huge platform

PS4 Shopee are available in regional and global networks

Perceived security (PC): (Adapted from Maqableh et al., 2015)

PC1 I think Shopee's electronic payment system is safe.

PC2 I consider the data related to customers' transactions using Electronic payment systems at Shopee is safe

PC3 I presume that illegal parties are banned to get my data that I supply during transactions at Shopee

PC4 I do not worry of the hacker assault of Shopee's electronic payment system

Perceived usefulness (PU): (Adapted from Maqableh et al., 2015)

PU1 Buying at Shopee enhances my buying performance

PU2 Buying at Shopee escalate my purchase productivity.

PU3 Buying at Shopee escalate my effectiveness

PU4 Buying at Shopee is practical

Habitual using the website (FW): (Adapted from Maqableh et al., 2015)

FW1 It is common for me to use Shopee

FW2 I repeatedly is looking for an item at Shopee

FW3 Buying process in Shopee is wellknown for me

FW4 It is a habitual for me to buy from Shopee 
User friendly perception (PE): (Adapted from Maqableh et al., 2015)

PE1 It is a piece of cake for me to learn about Shopee

PE2 My dealing with Shopee is transparent and articulate

PE3 I hope no problem to be familiar to use Shopee

PE4 Shopee is easy to use for online consumers

Perceived trust (PT): (Adapted from Maqableh et al., 2015)

PT1 I am convinced that my activities at Shopee are secured

PT2 My activities with Shopee tend to be reliable

PT3 Shopee will immediately notify me of any transaction problems

PT4 I am sure my activities with Shopee website or application will be crystalclear

\section{Intention of buying by employing EPS (P1):}

(Adapted from Maqableh et al., 2015)

P11 I will likely buy products from Shopee

P12 I will consider buying products from Shopee from now on

P13 Probably I would purchase products from Shopee from now on
P14 Every chance I have, I intend to buy products from Shopee

Factual buying by credit cards (AP) : (Adapted from Maqableh et al., 2015)

AP1 I often purchase online in Shopee by using my credit cards

AP2 I made intensive online purchases at Shopee using a credit card

AP3 Majority of my purchases in Shopee are paid by credit cards

AP4 I would like to continue my purchasing through Shopee by using credit card in the future

\section{Factual buying with cash-on-delivery system}

(AO) : (Adapted from Maqableh et al., 2015)

AO1 I often make online purchases from Shopee with money (cash-on-delivery)

AO2 I made intensive buying through internet from Shopee using money (cash-on-delivery)

AO3 Mostly, I purchased frequently through Shopee by cash payment (cash-ondelivery).

AO4 I would like to continue my purchasing through Shopee by cash in the future

APENDIX 2. Validity and Reliability Test

\begin{tabular}{|l|c|c|c|c|}
\hline \multicolumn{1}{|c|}{ Variable } & $\begin{array}{c}\text { Average Variance } \\
\text { Extracted (AVE) }\end{array}$ & $\begin{array}{c}\text { Composite } \\
\text { Reliability }\end{array}$ & $\begin{array}{c}\text { Cronbach' } \\
\text { Alpha }\end{array}$ & rho A \\
\hline Perceived reputation & 0,599 & 0,856 & 0,776 & 0,782 \\
\hline Perceived privacy & 0,581 & 0,847 & 0,760 & 0,765 \\
\hline Perceived size & 0,737 & 0,918 & 0,880 & 0.885 \\
\hline Perceived security & 0,656 & 0,882 & 0,821 & 0,852 \\
\hline Perceived usefulness & 0,720 & 0,911 & 0,870 & 0,873 \\
\hline $\begin{array}{l}\text { Familiarity with the } \\
\text { web }\end{array}$ & 0,750 & 0,923 & 0,889 & 0,923 \\
\hline $\begin{array}{l}\text { Perceived } \\
\text { friendly }\end{array}$ & 0,736 & 0,918 & 0,880 & 0,887 \\
\hline
\end{tabular}




\begin{tabular}{|l|c|c|c|c|}
\hline Trust perception & 0,613 & 0,864 & 0,791 & 0,807 \\
\hline $\begin{array}{l}\text { Purchase intention to } \\
\text { use EPS }\end{array}$ & 0,681 & 0,894 & 0,842 & 0,877 \\
\hline $\begin{array}{l}\text { Actual purchase using } \\
\text { credit }\end{array}$ & 0,880 & 0,967 & 0,954 & 0,967 \\
\hline $\begin{array}{l}\text { Actual purchase usimg } \\
\text { cash delivery }\end{array}$ & 0,901 & 0,973 & 0,964 & 0,990 \\
\hline
\end{tabular}

Source: Data analyzed by using SmartPLS Version3

\section{Creative Commons Attribution License 4.0}

\section{(Attribution 4.0 International, CC BY 4.0)}

This article is published under the terms of the

Creative Commons Attribution License 4.0

https://creativecommons.org/licenses/by/4.0/de

ed.en_US 